\title{
Ecohydraulics of river flow alterations and impacts on freshwater fish
}

\author{
Isabel Boavida1,*, Maria Díaz-Redondo², Juan F. Fuentes-Pérez ${ }^{3}$, Daniel S. Hayes ${ }^{4,5}$, Joaquim \\ Jesus $^{6}$, Miguel Moreira1 ${ }^{1}$, Oscar Belmar ${ }^{7}$, Núria Vila-Martínez ${ }^{7}$, Antoni Palau-Nadal ${ }^{8}$ and \\ Maria João Costa 1
}

${ }^{1}$ CERIS, Civil Engineering Research and Innovation for Sustainability, Instituto Superior Técnico, University of Lisbon, Portugal.

2 Instituto Superior Técnico, University of Lisbon, Portugal.

3 Centre for Biorobotics, Tallinn University of Technology, Tallinn, Estonia.

${ }^{4} \mathrm{CEF}$, Forest Research Centre, Instituto Superior de Agronomia, University of Lisbon, Portugal.

5 Institute of Hydrobiology and Aquatic Ecosystem Management, Department of Water, Atmosphere and

Environment, University of Natural Resources and Life Sciences, Vienna, Austria.

${ }^{6}$ CITAB, Centre for Research and Technology of Agro-Environment and Biological Sciences, University of Trás-os-Montes e Alto Douro, Quinta de Prados, 5001-801 Vila Real, Portugal.

7 IRTA, Marine and Continental Waters Program, Sant Carles de la Ràpita, Catalonia, Spain.

${ }^{8}$ Grupo de Investigación de Dinámica Fluvial (RIUS), Universidad de Lleida, Catalunya, España.

* Corresponding author: isabelboavida@tecnico.ulisboa.pt

Received: 27/11/18

Accepted: 13/03/19

\begin{abstract}
Ecohydraulics of river flow alterations and impacts on freshwater fish

The flow regime is a determinant of the ecological function and natural dynamics of a river system with a prominent effect on freshwater fish. Here, we introduce a number of contributions to the Special Session, "Ecohydraulics of river flow alterations and impacts on freshwater fish," that occurred at the XIX Conference of the Iberian Association of Limnology. The multidisciplinary contributions illustrate the impacts of river flow alteration on aquatic biota, describe mitigation measures and restoration actions to address river flow regulation, and present innovative tools for research in the ecohydraulics field. The research topics debated included environmental flows, river restoration, hydropeaking impacts on aquatic organisms, innovative methods and devices, and hydropeaking mitigation strategies. The importance of ecohydraulics as an emerging science was debated. The bridge between the disciplines of limnology and ecohydraulics was highlighted to understand flow alteration impacts and provide solutions to mitigate those impacts. This Special Session provided an opportunity to embrace ecohydraulic scientists in limnology research.
\end{abstract}

Key words: Ecohydraulics, limnology, flow alteration, freshwater fish

\section{RESUMO}

Ecohidráulica no contexto global das alterações do escoamento do rio e os impactos nos peixes de água doce

O regime de escoamento num rio é determinante para a função ecológica e dinâmica natural do sistema fluvial, com um efeito proeminente nos peixes de água doce. Neste estudo apresentamos as contribuições para a sessão especial - "Ecohidráulica das alterações do escoamento do rio e os impactos nos peixes de água doce", que teve lugar no XIX Congresso da Associação Ibérica de Limnologia, a fim de debater e compreender os efeitos da alteração de escoamento do rio nos peixes. As contribuições multidisciplinares ilustram os impactos da alteração de escoamento do rio no biota aquático, descrevem medidas de mitigação e ações de restauro fluvial para rios regularizados e apresentam ferramentas inovadoras para a investigação na área da ecohidráulica. Os principais tópicos debatidos foram: regime de caudais ecológicos, restauro de rios; impacto dos hidropicos em organismos aquáticos; métodos e ferramentas inovadores; e mitigação dos picos de caudal turbinado. A impor- 
tância da ecohidráulica como ciência emergente foi debatida. A ponte entre as disciplinas de limnologia e ecohidráulica foi realçada para analisar os impactos da alteração de escoamento num rio e apresentar soluções de mitigação. Esta sessão especial ofereceu uma oportunidade para incluir a componente ecohidráulica no estudo da limnologia.

Palavras chave: Ecohidráulica, limnologia, alterações de escoamento, peixes de água doce

\section{ECOHYDRAULICS}

The increasing demand for water resources has resulted in a continuous disruption of natural flow regimes with drastic changes in the physical character of riverine ecosystems. The continued flow alteration has severely changed rivers' hydro-morphological processes (Grant et al., 2013) resulting in uncharacteristic and homogeneous river habitats that adversely affect benthic invertebrates (White et al., 2016); riverine vegetation (Bejarano et al., 2018); and fish activities and critical life-stage events (Murchie et al., 2008; Young et al., 2011) that are likely to amplify to populations, communities, and the entire river ecosystem (Bain et al., 1988). The natural flow regime is therefore a determinant of the ecological function and natural dynamics of riverine systems (Poff et al., 1997). The dynamic role of the biotic (e.g., competition and predation) and abiotic (e.g., chemical and physical factors) partitions at a temporal and spatial scale set the structure of the aquatic ecosystem in which the flow regime plays the primary role (Gasith \& Resh, 1999). More difficult to establish, the biotic factors concern biological processes that widely depend on resource availability (Karr, 1981). More predictable and easily measured, the abiotic factors, divided into chemical and physical factors, are vital for the survival and persistence of individuals and affect the distribution of aquatic organisms (Rosenfeld, 2003; Boavida et al., 2011). The interaction of both the abiotic and biotic partitions can only be studied and understood using an integrative set of disciplines ranging from biology and ecology to hydrology and hydraulics, to provide a few examples.

Ecohydraulics emerged from the interface between the disciplines of ecology and hydraulics (Rice et al., 2010; Maddock et al., 2013) to understand the interactions between biotic and abiotic components of a riverine ecosystem that are associated with flow variability. It combines the study of physical properties and processes associated with moving water typical of hydraulic engineering and geomorphology, and their influence on aquatic ecology and biology (Nestler et al., 2016). The multidisciplinarity and interdisciplinarity of ecohydraulics often includes disciplines that are related to aquatic biology (e.g., physiology and evolution), engineering (e.g., hydraulics and hydrology), and other physical sciences (e.g., geomorphology). A survey of the proceeding papers from the International Symposiums on Ecohydraulics (1994-2016) by Casas-Mulet et al. (2016) enumerated 10 research macro-topics organized as follows: hydrology; hydraulic modelling; water quality; and flow, physical habitat, vegetation, invertebrate, fish, estuarine and social responses. These broad topics highlight the multidisciplinarity and interdisciplinarity of ecohydraulics research and its relevance for water resources management.

In an effort to determine the ecological responses to flow alteration, multidisciplinary teams have attempted a range of approaches, from numerical modelling (Mouton et al., 2007; Garcia et al., 2011; Boavida et al., 2018a) to empirical laboratory works (Costa et al., 2019a) and field studies (Santos et al., 2006; Ovidio et al., 2008; Alexandre et al., 2016) at various spatio-temporal scales. The spatial range extends from a local-scale (referring to the interaction of aquatic organisms and flow to address microhabitat hydraulics) to a large-scale (e.g., involving geomorphologic processes of erosion and sedimentation). Freshwater fish have always been a primary research target because of their prominence in riverine ecosystems (Pont et al., 2006) as justified primarily by the key role of spatial and temporal variabilities of the natural flow regime to fish population dynamics (Resh et 
al., 1988). Native organisms have evolved life-history strategies and morphological adaptations to respond to these flow variations (Lytle \& Poff, 2004). Over time, regulated rivers can better support generalist fish species, typically non-native taxa, compared to indigenous species, providing the former a competitive advantage over the latter (Copp et al., 2005).

Furthermore, in regulated rivers, because of hydroelectricity production, flow is periodically disrupted by extreme and short-duration fluctuations in discharge during daily peaks of energy demand (Cushman, 1985; Young et al., 2011), raising concerns regarding the ability of fish to respond to the quickly changing environment, and the costs and time to react to constant changes (Costa et al., 2019a). In addition, hydroelectric turbines can cause massive fish mortality because of abrupt changes in pressure, cavitation, shear forces, turbulence, and mechanical shock (Havn et al., 2017).

The described impacts associated to flow regulation highlight the need to overcome these problems by forming multidisciplinary teams capable of generating quantitative information regarding these impacts on freshwater fish. Thus, it is imperative to develop innovative methods and tools to describe the aquatic environment and present novel solutions to minimize and mitigate adverse impacts. Promoting successful restoration actions followed by monitoring schemes are also important cues during the process.

The aim of the Special Session, "Ecohydraulics of river flow alterations and impacts for freshwater fish," held at the XIX Conference of the Iberian Association of Limnology was to combine the disciplines of limnology and hydraulics to assess and understand the impacts of river flow alterations on freshwater fish and provide solutions to mitigate these impacts. Limnology is closely related to aquatic ecology and hydrobiology, studying aquatic organisms in particular with regard to their hydrological environment (Wetzel, 1981). Hydraulics focuses on applied engineering using the properties of fluids (Chow, 1973). The interaction between these two disciplines is vital to answer ecohydraulic challenges regarding fish and flow alteration.

\section{ECOHYDRAULIC CONTRIBUTIONS TO LIMNOLOGY}

\section{River restoration}

The need to maintain the sustainability of aquatic ecosystems by applying local restoration measures has been widely recognized by ecohydraulic research, river management, and environmental policies (Pretty et al., 2003; Nilsson et al., 2007), in particular the EU Water Framework Directive (EU, 2000). Despite the recognition and an increased number of restoration actions, most projects are still undertaken on a trial basis (Downs \& Kondolf, 2002), often based on the assumption that implementing a certain restoration action will surely improve the ecological integrity of the aquatic ecosystem. However, scientists and river managers should be aware that undertaking local restoration measures is not a guarantee of success (Maire et al., 2015). Given both the high costs involved and socio-administrative expectations, habitat improvement projects must successfully apply science-based tools. Thus, restoration projects should incorporate a proper assessment of the potential outcome based on the specific ecological attributes of the river (Woolsey et al., 2007) to verify the success of the proposed actions.

Díaz-Redondo et al. (2018) used a novel framework to evaluate river restoration in an urban river reach. The authors applied geomorphological metrics and hydraulic variables associated with potential preferential conditions for autochthonous fish fauna, whose populations are greatly reduced (Tánago et al., 1999), to assess the initial natural habitat recovery. Throughout the 20th century, in a similar manner to other urban river segments (Petts, 2007), the Manzanares River in Madrid, Spain, was channelized to allow for intensive urban development, and nine small dams were built to maintain a view of a large deep river. As part of the renaturalization initiative by the Madrid City Council, the opening of urban dam gates during the spring of 2016 potentially allowed for habitat improvement facilitating colonization by vegetation and fauna. First, from the Geographic Information System (GIS) analysis of aerial photographs for the years 
2015, 2016, and 2017, geomorphological metrics were applied including areas $\left(\mathrm{m}^{2}\right)$ of islands and bars, and shoreline length as the sum of perimeters $(m)$ in contact with water. In addition, the ratios of areas and shoreline lengths per patch (island or bar) were also calculated. Second, hydraulic-habitat models based on species-specific preference curves were applied. Two-dimensional (2D) hydraulic modelling was performed using IBER 2-D (Bladé et al., 2014) and outcomes of water depth, flow velocity, and shear stress were evaluated against the preferences of three target autochthonous fish species the Iberian barbel (Luciobarbus bocagei Steindachner, 1864), Southern Iberian chub (Squalius pyrenaicus Günther, 1868), and Southern Iberian spined-loach (Cobitis paludica de Buen, 1930). Results from geomorphological metrics indicate that the increase in number, area, and shoreline length of islands and bars was remarkable following the gate opening. Moreover, initially, sedimentation produces many small- and medium-sized patches that later on do not significantly grow in number but, instead, increase in size. All these metrics are an indication of an improvement in habitat quality and availability (Tockner \& Stanford, 2002). In this sense, results from 2D hydraulic modelling show that current habitat conditions related to shallower water depths, different velocities within the channel, and new sand sedimentation promote potential preferential habitats for native fish fauna. In conclusion, over a short period of time, the improvement in habitat conditions has been remarkable. Overall, more studies are required regarding the evolution of habitat conditions following urban river rehabilitation, particularly from the perspective that partial recovery of natural habitats in an urban stretch can lead to the improvement of its ecological potential, as required by the Water Framework Directive (Gumiero et al., 2013).

The recognition of river flow alteration worldwide has led to the establishment of environmental flows (hereafter e-flows) (Arthington et al., 2018). An e-flow regime implemented downstream of dams play an essential role in the conservation of freshwater ecosystems (Arthington et al., 2006; Rivaes et al., 2017). Setting an e-flow regime involves identifying the quantity, timing, and quality of water flow required to sustain freshwater and estuarine ecosystems, as well as the human livelihoods and wellbeing that depend upon these ecosystems (Arthington et al., 2018) over time and space. Achieving this level of detail can be resource demanding (Arthington et al., 2006). Boavida et al. (2018b) proposed an undemanding method to transfer the inter-annual variability associated with e-flows to another river reach in the same catchment when similar morphodynamic conditions and flow-ecological relations are verified. Several methodologies have been developed to define e-flows with different degrees of effort. According to Tharme (2003), the existing e-flow methodologies can be differentiated into hydrological, hydraulic rating, habitat simulation and holistic methodologies. From an ecohydraulics perspective, habitat simulation methodologies are widely accepted to define e-flows (Acreman et al., 2014). With an emphasis on complex, hydrodynamic habitat modelling, these methodologies require immense amounts of data. The time and resource consumption of these actions (Palmer et al., 2005) highlights the need to implement successful methodologies that require less data or data more easily collected while maintaining the same level of achievement. Transferring flow-ecology relationships can be a successful measure to assist regional-scale e-flow assessments (Chen \& Olden, 2018). The habitat availability for a target species in a natural, non-regulated stream acts as the reference condition (guiding image) for comparing the degree to which an environmental flow scenario deviates from the natural flow regime (Boavida et al., 2012). The closer the e-flow scenario is to the reference condition, the "healthier" the e-flow scenario is determined to be (Nilsson et al., 2007). Conversely, the further from the reference condition, the less healthy it will be. Therefore, this study assessed the viability to transfer the pre-defined e-flow regime - set according to the reference habitat availability proportionally, from an upstream to a downstream river segment. The similarity among the morphodynamic conditions was guaranteed as well as the flow-ecological relationships. The pool of fish species between the two studied reaches was also similar. Finally, inter-annual 
variability was set the same for both reaches. The results indicated a good adjustment between the e-flow scenario and the reference condition for the river segment that received the e-flow values transferred from the upstream river-segment. This study improves knowledge of the extensive literature on e-flow methodologies. Further, it sets the e-flow based on habitat simulation methodologies by transferring these values among similar river reaches.

\section{Impacts of hydropeaking on aquatic organisms}

The impacts of river flow alteration on freshwater fish have been addressed by the ecohydraulic community, with relevance for sub-daily rapid alterations of flow downstream of hydropower stations. Cushman (1985) first referred to hydropeaking as the operational maneuvres that occur in hydropower plants in response to electricity demand to control large and rapid (within minutes) changes in discharge by powering -on or -off hydro-turbines, resulting in rapid flow changes in tailwaters. During non-peak periods, hydropower facilities store water in a reservoir resulting in low flows downstream of the hydropower plant (i.e. environmental flows), while during peak periods, power is generated and water is rapidly released, increasing the velocity and water depth downstream of the facility. The unpredictability and intensity of flow variations are rather permanent and more frequent than those resulting from natural flows, such as rapid snowmelt and precipitation (Shuster et al., 2008). Because of the unpredictability and intensity of flow variations, these rapid flow fluctuations likely influence the natural structure of the riverine ecosystem (Young et al., 2011). Long-term hydropower plant operations result in strong morphological, hydraulic and water quality alterations. These alterations include bank and soil erosion, substrate composition (siltation and armouring of the substrate), and continuous shifts in sediment transport processes (Schmutz et al., 2015) caused by the continuous changes in water level, flow velocity, water turbulence and bed shear stress (Shen et al., 2010). This may lead to severe impairments to fish rearing and growth, fish migration and spawning, and to the benthic invertebrate community (Bruno et al.,
2016). Juvenile fish are particularly vulnerable to hydropeaking events, leading to drifting and stranding (Halleraker et al., 2003), which can ultimately reduce recruitment of the entire population (Schmutz et al., 2015). Because of this, during the last decade, research on hydropeaking impacts has rapidly increased (Bejarano et al., 2018). The growing awareness of the impacts of hydropower plants on the downstream ecosystem has increased in parallel with the development of hydropower, given the increasing global demand for hydroelectricity production. Climate change awareness has increased the pressure on hydropower production (Sawin \& Martinot, 2010) because of its efficiency, high reliability and predictability, lack of carbon emissions, and low operating costs. These issues point out to an urgent need to overcome this problem by generating quantitative information regarding hydropeaking impacts to find innovative solutions that allow for a sustainable development of hydropower energy. The recognition of this is reflected in the number of contributions describing hydropower impacts and mitigation measures that this Special Session has received. Ranging from field case-studies to laboratory work, research on hydropeaking has never before seen such interest.

To understand fish behaviour when subjected to hydropeaking events, Hayes et al. (2018a) used a comprehensive national database to assess the response of juvenile salmonids to natural and artificial flow fluctuations in Austrian Alpine rivers, in which river hydrology ranges from natural flow regimes to extensive hydropeaking, and morphology from natural to channelized. Hydrological metrics were calculated according to Greimel et al. (2016), whereby sampling sites were grouped into four categories: (1) reference, (2) hydro-fibrillation (low-intensity flow fluctuations), (3) hydropeaking (high-intensity flow fluctuations), and (4) glacier (natural hydropeaking) (Hayes et al., 2018b). To describe the morphological variability of the assessed river reaches, the coefficient of variation was calculated based on aerial image interpretation of the bankfull river width, which allows comparing the width variability of distinct rivers of different sizes (for details see Greimel et al. (2017)). Regarding young-of-the-year brown trout (Salmo trutta 
Linnaeus, 1758) and European grayling (Thymallus thymallus Linnaeus, 1758) abundance in their respective fish zones, initial results showed that sites classified as hydropeaking are distinguished from the three other hydrological categories. Hydro-fibrillation and glacier sites showed lower fish abundances than those of the reference sites, although it was not significant. Downramping rates during mean and high water flow range situations seem to be among the parameters governing juvenile fish abundance, whereby the pattern corresponds with stranding thresholds established through experimental studies (Moreira et al., 2019) particularly for the brown trout in the metarhithral. For the grayling in the hyporhithral it is not as clear, probably because of the number of stressors generally found in this fish region (Schinegger $e t$ al., 2018). Results also showed the additional influence of river morphology, whereby more nature-like sites tend to have a higher juvenile abundance than those that are channelized ones (Hayes et al., 2018b) as the former can offer higher habitat suitability than that of the latter (Hauer et al., 2014)

The scientific community as well as fishery and river managers agree with the view, that promoting habitat heterogeneity through more natural sites can effectively mitigate the impacts of hydropeaking and promote self-sustainable fish populations downstream of hydropower dams (Hauer et al., 2014; Alexandre et al., 2016). Experimental flume-based research has proposed morphological measures to mitigate hydropeaking consequences. For example, lateral refuges (Ribi et al., 2014), substrate heterogeneity (Chun et al., 2010), and alternative cover structures (Vehanen et al., 2000) have been studied as refuge for salmonids during hydropeaking events. Still, considerable uncertainty remains regarding the design of effective mitigation measures based on fish responses, particularly when applied to cyprinids, which include a high proportion of endangered species in central Europe and the Iberian Peninsula (Santos et al., 2018). Changes in critical life-cycle events of the Iberian barbel (e.g., growth and reproduction) have been attributed to anthropogenic streamflow variability (Alexandre et al., 2015). For example, smaller home ranges were associated with natural seasonal flow variability of a non-regulated river, whereas wider spatial scale movements were associated with a river affected by hydropeaking (Alexandre et al., 2016). It is certain that flow regulation has extensive impacts on freshwater fish structure and function. However, it remains difficult to understand which changes in the flow components trigger specific movement patterns or habitat preferences. In this sense, the ecologi- a)

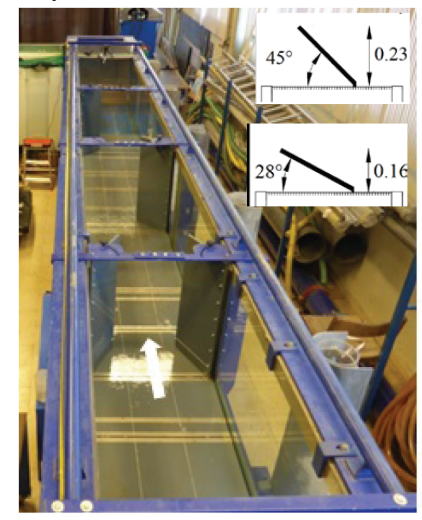

b)

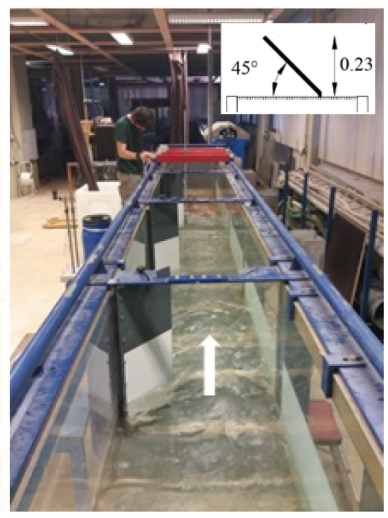

c)

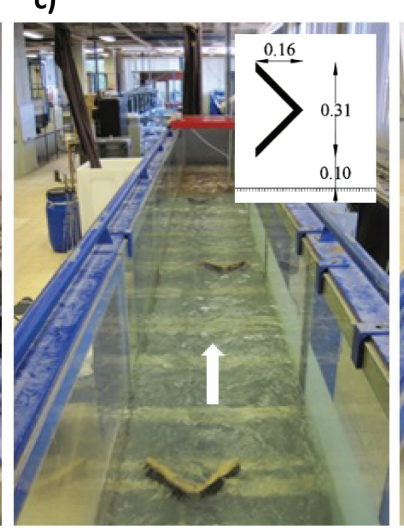

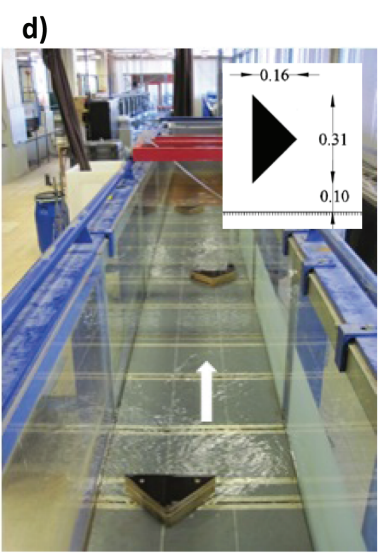

Figure 1. Structure configurations tested according to Costa et al. (2018a). (a) and (b) represent the lateral deflectors and (c) and (e) the v-shaped structures and the solid triangular pyramids respectively. A detail of the refuges dimensions $(\mathrm{m})$ is shown. Configuração das estruturas testadas por Costa et al. (2018a). (a) e (b) deflectores laterais e (c) e (d) estruturas em v e pirâmides, respetivamente. A dimensão ( $m$ ) dos refúgios é apresentada em detalhe. 
cal impacts of hydropeaking and this cause-effect relationship should be further scrutinized to provide the necessary tools for fishery managers to improve population dynamics and conserve endangered fish species.

To fill this gap, Costa et al. (2018a) adopted a multidisciplinary approach, in which movement behaviour was combined with a detailed hydraulic characterization to evaluate the use of lateral and instream structures as potential refuges for Iberian barbel (Luciobarbus bocagei) affected by rapid flow fluctuations (Costa et al., 2018b; Costa et al., 2019a) (Fig. 1). This consisted of flow field measurements using Acoustic Doppler Velocimetry (ADV) technology and fluid-body interactions with the objective to better interpret fish responses. Using this approach, it was possible to conclude that the movement pattern demonstrated by the Iberian barbel was diverse and not always proportional to the severity of the flow event. For example, during the peak events with structures the individual sprints were more pronounced, whereas group behaviour increased under base flow and hydropeaking conditions without structures. Although the hydraulic characterization showed that lateral deflectors and $\mathrm{v}$-shaped structures provided low velocity areas that could potentially mitigate the severity of peak flows, the flow complexity created by the presence of the structures represented an additional constraint for fish, hindering their ability to find refuge behind the structures. The distinct behavioural patterns were a result of the hydraulic conditions created by the flow event and the structures' configurations. The use of this integrated approach strengthened the interpretation of fish responses and minimized misleading conclusions, thus contributing to the design of more effective mitigation measures in response to hydropeaking consequences.

In addition to affecting fish movements and behaviour as shown by Costa et al. (2018a), artificial flow fluctuations decrease the density, composition, and biomass of the macroinvertebrate community (Bruno et al., 2016). Palau-Nadal et al. (2018) studied the effects of hydropeaking (ranging from $<2 \mathrm{~m}^{3} / \mathrm{s}$ to $12 \mathrm{~m}^{3 / \mathrm{s}}$ ) on the water temperature, macroinvertebrate community, physical habitat, and brown trout population
(Salmo trutta Linnaeus, 1758) of a Pyrenean river, taking as a reference a near reach of the same river without hydropeaking. The study was conducted during the summers of 2011 and 2012. Hydropeaking affected the macroinvertebrate community through two factors: 1) variations in flow (alteration of the physical habitat) that generate changes in the density, composition, and trophic structure of the community (e.g., an increase in the ratio of grazers/shredders); and 2) changes in water temperature that alter the biological cycle of some aquatic insects in a temporal lag with respect to the reach without hydropeaking (e.g., Heptageniidae and Athericidae). These effects, however, quickly decreased downstream and were barely detected $2 \mathrm{~km}$ downstream. The longitudinal variation in the downstream impacts of flow regulation is highly dependent on the existence of a tributary $(1 \mathrm{~km}$ from the hydropower plant) of sufficient size and flow to alter the upstream discharge and hydraulic lamination. The physical habitat of the brown trout changed in response to the hydroelectric peak flows, particularly the availability of habitat for fish fry decreased as a consequence of the unfavourable hydraulic conditions associated with high flows. However, this change was not reflected in the density and biomass of the trout population in the altered river reach, where both variables presented higher values than those in the reference section, without appreciating the limitations of the adult and juvenile stages. The density and structure of the brown trout population changed between the two years (2011 and 2012) in the reference section, which can be related to a natural flood (of $40 \mathrm{~m}^{3} / \mathrm{s}$ ) that occurred during April 2012, coinciding with the time of the start of the fry stage in the zone. In contrast, the hydropeaking reach showed few changes between the two years of study, suggesting that its population of brown trout was more resilient and resistant to a natural flood, being in itself confirmed by a low proportion of fry.

\section{Hydropeaking mitigation: regulations and thresholds}

Despite the increase in hydropeaking research, with different studies evaluating the effect of 
flow alteration on aquatic biota and evaluating the success of mitigation measures, knowledge of hydropeaking targets from which an impact occurs remains scarce (Young et al., 2011). Moreira et al. (2018) presented an extensive review of the thus far established hydropeaking targets and thresholds regarding outputs from the scientific community (by conducting a Scopus literature search), as well as indicator values from national regulations and guidelines. The study found that only a few European countries (Switzerland and Austria) have legal regulations regarding hydropeaking through flow thresholds (Moreira et al., 2019). Other countries, such as Norway, have environmental legislation that can be used to force hydropeaking mitigation measures. Most mitigation thresholds in the literature address the effect of downramping on stranding of salmonids and were mostly established through trials in experimental channels. Established downramping thresholds range from < $0.1-0.2 \mathrm{~cm} / \mathrm{min}$ for larvae (of Salmo trutta Linnaeus, 1758, Thymallus thymallus Linnaeus, $1758)$ to $c a .0 .2-0.4 \mathrm{~cm}$ for early juveniles $(S$. salar Linnaeus, 1758; S. trutta Linnaeus, 1758; T. thymallus Linnaeus, 1758; Oncorhynchus kisutch Walbaum, 1792; O. mykiss Walbaum, 1792). In addition to downramping velocity restrictions, common qualitative goals target the prevention of redd desiccation between peak flows and mitigation approaches aim at increasing base flows and/or decreasing peak flows (Moreira et al., 2019). Regarding other fish group species (e.g., cyprinids) and parameters (e.g., peak duration and time between peaks), a lack of quantitative mitigation thresholds remains. Nevertheless, the literature indicates that multiple aspects have to be considered when assessing such thresholds. To aid in this process, Moreira et al. (2018) proposed that mitigation thresholds must be based on key species, including particular features regarding life stage, season, and time of day. These must be combined with site-specific morphological characteristics as the effects of river morphology influences hydropeaking parameters that are essential in defining the thresholds. Thus, the principles laid out in their approach may benefit impacted organism groups in hydropeaking reaches through the establishment of ecologically based relevant mitigation thresholds.

\section{Innovative methods and devices}

Better knowledge of fish species movements and behaviour when affected by flow variations is needed to improve the protection of individual fish and achieve self-sustaining fish populations. The planning and design, as well as the probability of success of the proposed mitigation measures, requires innovative monitoring and observational methods, new software tools, and innovative technical devices to enhance the level of assessment and prediction of the measures. Currently, in situ analysis of fish habitat preferences is typically based on point measurements of the physical environment (e.g., time averaged velocity, water depth, substrate type, and underwater vegetation presence) (Santos et al., 2018). This discretization may lead to an oversimplification of the hydrodynamic characteristics of the aquatic environment, mainly because these

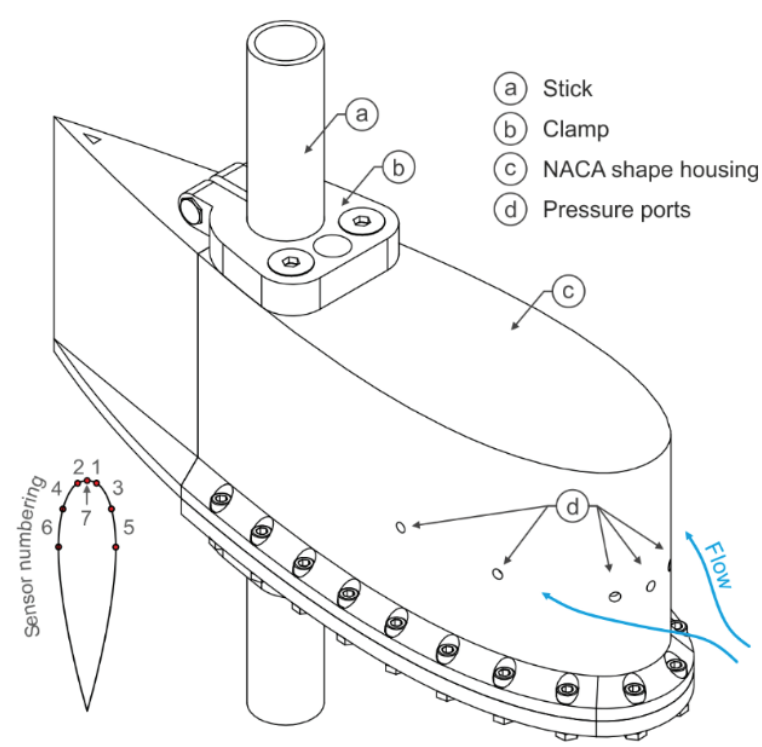

Figure 2. Artificial lateral line probe (modified from Fuentes-Pérez et al. (2018)). The NACA025 body shape is outfitted with six differential pressure sensors $(1-6)$ and one absolute (7) pressure sensor. Sonda artificial da linha lateral (modificado de Fuentes-Pérez et al. (2018)). A forma NACA025 apresenta seis sensores de pressão diferencial (1-6) e um sensor de pressão absoluta (7). 
metrics ignore the physical interactions between the variables and lack the temporal rate at which fish experience and react to hydrodynamic stimu1i. To attempt to address this complex problem, Fuentes-Pérez and Tuhtan (2018) developed a new measuring device based on the sensing principles of fish: the artificial lateral line probe (ALL) (Tuhtan et al., 2016) (Fig. 2).

Fish have evolved in water and unlike terrestrial species they have developed an external sensory system able to sense the water's hydrodynamic characteristics. This physiological adaptation is termed the lateral line (Fig. 3). The lateral line provides sensory input that contributes to many common behaviours in fish, such as prey and predator detection (Coombs et al., 2001; Coomb et al., 2012), obstacle avoidance (Hassan et al., 1992), and rheotaxis (Montgomery et al., 1997) or schooling (Pitcher et al., 1976), among others.

The lateral line probe (LLP) provides a new technology for understanding aquatic ecosystems and is based on the interaction between the sensor, flow, and aquatic environment. Thus, the LLP provides a new type of bio-inspired sensing device for flow measurement (Fuentes-Pérez et al., 2015) and aquatic environment classification The LLP uses a time-synchronized array of rapid pressure sensors installed over a hydrodynamic body (Fig. 2). The benefits of this sensing system to ecohydraulics and water managers are as follows: 1) it performs simultaneous measurements in both space and time in contrast to point measurement devices (e.g., acoustic Doppler velocimeters or propellers); 2) it considers the interaction of the fluid with the body of the probe (spatially distributed sensing) and the surrounding underwater environment (e.g., rocks, plants, and walls); and 3) it measures a sampling rate higher than any other field tool (tested and validated up to $200 \mathrm{~Hz}$ ) and within the same range of the fish lateral line system. The LLP has the potential to represent the distributed sensing capacity of fish, bringing new sources of flow and underwater environmental information, as well as immediate opportunities to diverse ecohydraulics' fields. For example, in fishway research ALLs have been demonstrated for fish flow preferences and to sample and classify different hydrodynamic scenarios in a vertical slot fishway, contribut- a)

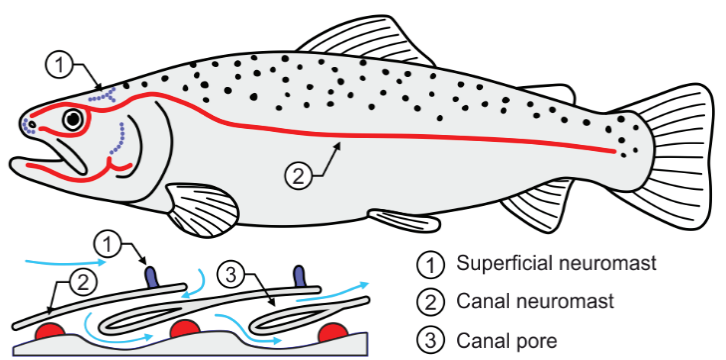

Figure 3. Lateral line system (Tuhtan et al., 2017); (a) Distribution of neuromasts; (b) Superficial and canal neuromasts. Sistema da linha lateral (Tuhtan et al., 2017); (a) Distribuição dos neuromastos; (b) Neuromastos superficiais e de canal.

ing to its retrofitting (Tuhtan et al., 2018). In hydropeaking studies, ALLs have shown the availability to characterize the unsteady conditions produced by different hydrodynamic scenarios and relate them to fish behavioural responses (Costa et al., 2019b). Considering these results, ALLs have the potential to become a multipurpose tool to monitor the complex aquatic environment experienced by fish.

To date, the use of ALLs in the field has been limited to daily monitoring campaigns for fish preference studies or hydrodynamic characterization. Its use for long-term monitoring would require 1) an external datalogging system, 2) a robust design able to handle the target hydrodynamic conditions, and 3) a holding platform. In Ristolainen et al. (2018), the described ALL-working principle was successfully implemented in a device (the Hydromast) designed for long-term monitoring of rivers and open oceans.

Alternatively, proactive improvement measures may be needed to guarantee intervention success. Potamodromous fish population survival can be increased using innovative technical solutions based on fish behavioural systems. Non-physical barriers based mostly on different aversive conditions have been tested, namely electric and magnetic fields, water velocity barriers, hypoxia and hypercapnia, pheromones, strobe lights, bubble curtains, and acoustic deterrents (Noatch \& Suski, 2012), to reduce fish mortality. The selective study of the repulsive behaviour of a certain species allows one not only to remove fish from traps promoted by the hydraulic structures 
during their migratory movement, but also allows one to use these same repulsive stimuli to guide the fish, particularly to fishway zones, when functional, but are of reduced attractiveness. Jesus et al. (2018b) presented acoustic or luminous stimuli as a repulsive effect for fishes. Both in an isolated and in a combined manner, acoustic (Sweep-up: < $2000 \mathrm{~Hz}$ ) and luminous (Strobe Light: 600 flashes/minute) stimuli, as well as a bubble curtain, were tested on the salmonid species Brown trout (Salmo trutta Linnaeus, 1758) and the cyprinid species northern straightmouth nase (Pseudochondrostoma duriense Coelho, 1985) and Iberian barbel (Luciobarbus bocagei). In the tests performed with the isolated stimuli, a repulsive sensitivity to the luminous stimulus was verified in the salmonid species (preliminary data under analysis), while the cyprinid species showed a higher sensitivity to the acoustic stimuli (Jesus et al., 2018a). The bubble curtain, in isolation, did not show a behavioral sensitivity in any of the species. In the tests performed in a combined acoustic/light/bubble manner (behavioral barrier), all species showed similar and elevated repulsive sensitivities. These results show the great potential of fish behavioural barriers based on combined systems of acoustics/lights/bubbles, particularly in salmo-cyprinid water courses. The development of behavioural barriers adapted to freshwater species is an important tool to guarantee fish migration, considering the upstream and downstream movement of threatened potamodromous species near dams. These systems will provide conditions for fish to repel from specific structures (channel turbines, pumping systems), avoiding the massive mortality detected in several dams and contributing to the conservation of autochthonous fish populations in regulated rivers.

\section{Fish-based biological indicators}

A great number of indexes and metrics have been developed to assess ecological quality in freshwater ecosystems (Benejam et al., 2015); many of these biological indicators have shown to date to be insensitive to flow regime changes or hydrological alterations. Therefore, there is a need to further understand the relationships between such indicators and flow regimes.
Belmar et al. (2018b) analysed the relationships between three fish-based biological indicators widely used in Spain and a set of hydrological descriptors, in the low section of a large Mediterranean River using different spatiotemporal scales. The biological indicators were the Indexes of Biotic Integrity in Catalan rivers (IBICAT2010 and IBICAT2b) and the new European Fish Index (EFI+) (EFI+CONSORTIUM，2009), whereas the hydrological descriptors were water velocity, depth, and a set of sub-daily and daily hydrological indexes (Table 1) modified from Bevelhimer et al. (2015) and Olden \& Poff (2003), respective1y. Fish samples were interannually collected, within a period of 11 years in 6 different transects of the lower Ebro River that were expected to show similar fish communities (except one transect with extreme flow regulation). Hydrological indexes were computed using flow records of different lengths previous to the sampling date. IBICAT2010 was the index most correlated with the flow regimes, but the results were highly dependent on the spatiotemporal scale considered. Daily hydrological indexes showed correlations with biological quality when they were computed using flow records between 9 and 36 months previous to sampling, whereas sub-daily indexes responded better using records between 3 and 9 months. In contrast to that expected, even a priori similar sampling transects showed clearer ecohydrological relationships than those of the others, suggesting the influence of hydromorphological variability on the obtained biological quality scores. The transect that provided the clearest relationships showed potential breakpoints for water depth, the mean of the annual minimum flows (ML14), the low flow discharge (ML23), and the standardized maximum hourly ramping rate (dstMHramp). Such breakpoints constitute a separation between "poor" and "bad" status and can be useful to develop management strategies in the Ebro River or other areas. The dependence of the results on the spatial scale highlights the need to improve knowledge regarding the role of channel morphology (including aquatic habitats) on the effects that flow regimes cause in aquatic communities (Belmar et al., 2018a). 


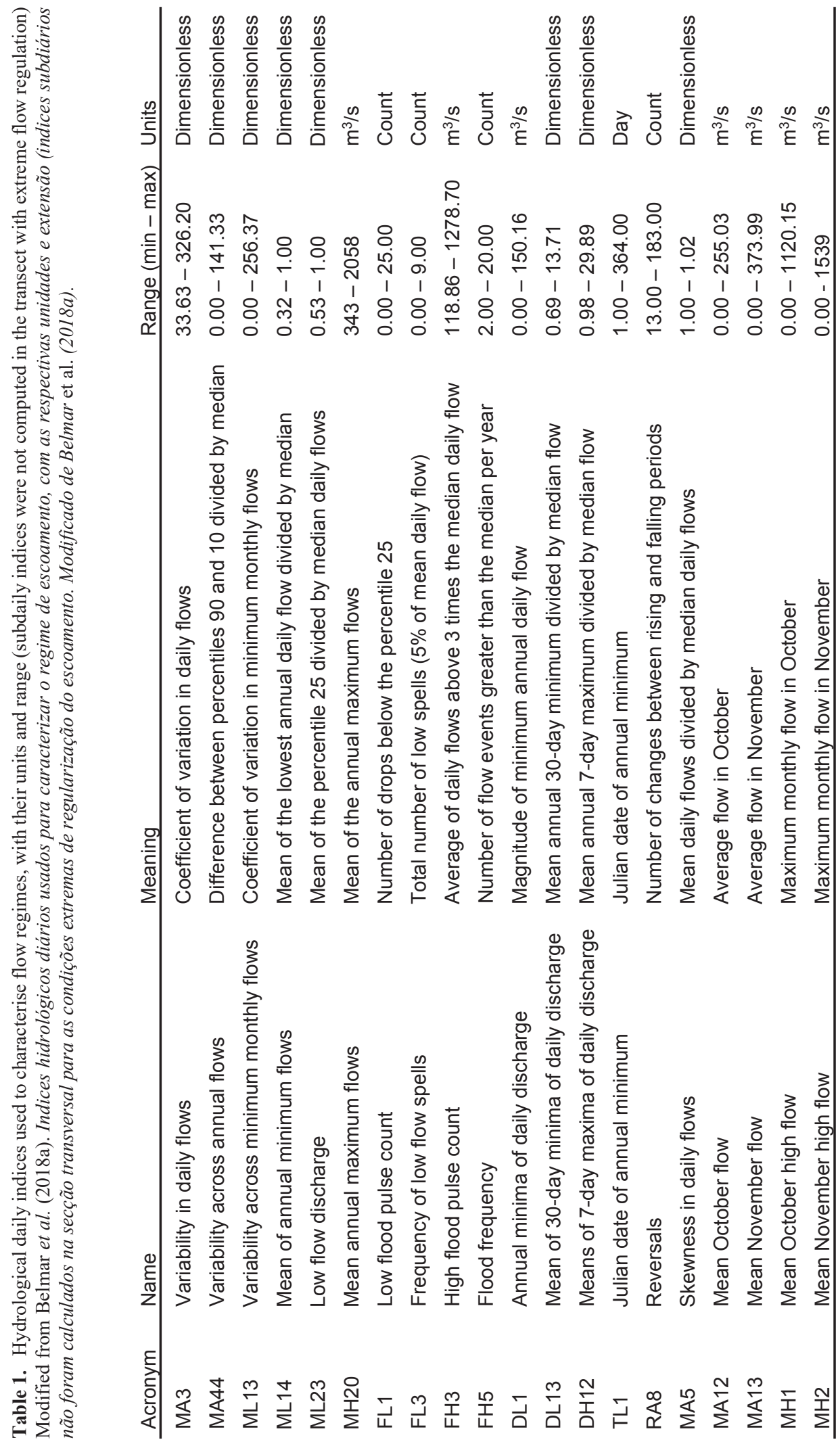




\section{PERSPECTIVES}

Ecohydraulics research has undergone major development during the last decade. A demonstration of this is the recently published papers regarding the "ecohydraulics" topic (Lancaster \& Downes, 2010; Nestler et al., 2016; Casas-Mulet et al., 2016) describing contributions from hydraulics, river engineers, ecologists, biologists and geomorphologists. Additionally, the use of the term "ecohydraulics" in Special Issues has appeared in the most relevant journals such as "Ecohydraulics: Recent Research and Applications" in the Journal of Hydro-Environment, "Ecohydraulics: linkages between hydraulics, morphodynamics and ecological processes in rivers" in Ecohydrology, "From microhabitat ecohydraulics to an improved management of river catchments: bridging the gap between scales" and "Bridging the gap between fish behaviour, performance and hydrodynamics: an ecohydraulics approach to fish passage research" in River Research and Applications, and the to be published "Integrating Ecohydraulics in River Restoration: Advances in Science and Applications" in Sustainability.

The ecohydraulics research field appears to address an unanswered question regarding the interaction of aquatic biota with the environment, and consequently, predicts how biota will be affected by changes in river flow. The wide scope of contributions from this Special Session emphasizes the importance of ecohydraulics for freshwater ecosystem management and its contribution to limnology. As limnology integrates physical and biological processes of inland waters, ecohydraulics studies the changes in physical processes caused by flow variability and their influence on the freshwater ecosystem. Based on the global context of river flow alterations and impacts on freshwater fish, the contributions were rather diverse and explored important aspects of the impacts of flow alteration. In particular, the scientific contributions highlighted the need to promote river restoration actions, develop e-flows, and propose mitigation measures that promote self-sustaining fish populations. Hydropeaking impacts on aquatic organisms were also studied by conducting laboratory and field studies as well as covering hydropeaking mitigation thresholds by reviewing existing literature on the subject. In addition, fish-based indicators were assessed. Finally, innovative devices such as procedures to measure the hydrodynamic conditions based on the sensing principles of fish and the use of acoustic or luminous stimuli as a repulsive effect for fishes were proposed.

Regardless, many unanswered questions remain regarding the link between physical processes that occur in this highly unstable environment and the responses of fish biota. To address these and other challenges at the ecology and hydraulics interface there must be equal contribution from both disciplines. In fact, there has been criticism for the lack of ecological relevance to some ecohydraulic approaches (Lancaster \& Downes, 2010). While analysing published papers in the ISI Web of Knowledge database between 1997 and 2009, Rice et al. (2010) suggested that ecohydraulics is dominated by engineers and physical scientists and that there is less involvement from ecologists and biologists, reinforcing the need to engage these scientists to solve ecohydraulic issues (Casas-Mulet et al., 2016). In contrast, work conducted by ecologists without adequate input from physical engineers will likely result in criticism, particularly considering the misapplication of flow equations. Both contributions are complementary and necessary to understand the effects of flow alterations and impacts on freshwater fish and propose successful mitigation measures. Despite the recognition of this and the efforts to better integrate hydraulic and biological tools to analyse and predict ecological responses to aquatic environmental changes (Lamouroux et al., 2013), there is still a long way ahead. The participation of ecohydraulicians in conferences on inland freshwaters supporting a high level of biodiversity such as the XIX Conference of the Iberian Association of Limnology is more than welcome. Moreover, ecohydraulics lacks fundamental concepts and practices, a problem shared by many new interdisciplines and interdisciplinary academic programs (Nestler et al., 2016). Ecohydraulics focuses on applied research to address practical problems such as the definition of environmental flows, river restoration actions, fish passage design criteria, hydrope- 
aking impacts and mitigation among others (Lamouroux et al., 2010). Ecology is mostly grounded in fundamental science to address the interactions of organisms and the surrounding environment. Ecohydraulics can be integrated into limnology by combining different disciplines to understand the physical processes caused by flow alterations and the consequent ecosystem responses, while incorporating fundamental research to study inland aquatic ecosystems. Therefore, the bridge between the two disciplines is of growing interest.

Ecohydraulics as a field of research is still young; new developments will likely occur in the near future. Fuentes-Pérez \& Tuhtan (2018) and Jesus et al., (2018b) foresee more engagement from another field of research with ecohydraulics - electronics and informatics. The development of new tools and devices to assess fish behaviour or the implementation of mitigation and restoration measures needs to be assessed with developers by shortening the bridge between ecohydraulics and emerging technologies. For this we, as ecohydraulicians, need to be more proactive. We need to push boundaries to increase communication and collaboration among different disciplines.

Although new developments are occurring in ecohydraulics a major gap remains between the scientists that conduct science and end users as well as authorities that are responsible for implementation of actions (Casas-Mulet et al., 2016). Moreira et al. (2018) presented an overview of the current knowledge and a review of established mitigation thresholds and showed distinct regulations remain largely lacking. This underlines the need to engage both scientists and legislators. Science is driven to address unanswered questions and river managers are the key drivers during the decision-making process. Science is useless without river managers and contrariwise. Most restoration actions and monitoring schemes need to be implemented to assess their success and improve those yet to come, as was shown in Díaz-Redondo et al. (2018). Moreover, river managers, hydraulic companies, and environmental agencies are responsible for recognizing knowledge gaps and explaining this need to the scientific community. It should be a win-win process.

Most ecohydraulics research regarding flow alteration is designed to answer practical ques- tions, frequently completed in the field (Alexandre et al., 2016), at a laboratory scale (Ribi et al. . 2014), or by applying numerical modelling (Boavida et al., 2017). Often the focus is on the ecological processes that may be influenced by river flow alterations by quantifying the response variables that are directly related to the process and can be isolated. Costa et al. (2018a) presented a promising mitigation measure for hydropeaking for an Iberian cyprinid fish. Nevertheless, the results need to be further upscaled or tested in a real environment to improve our understanding of the effectiveness of the implemented measures occurring in nature. How the ecosystem will react to these actions is often the remaining question.

Constant changes in society and environment are followed by a continuous change in the problems that need to be addressed in aquatic ecology. The cost of the application of such measures, methods, or tools in terms of time and resources is a key aspect during the process. There is increasing pressure to solve questions in less time and using fewer resources. Therefore, the need to develop cost-effective measures to improve our knowledge of the aquatic environment is paramount. Examples, such as that presented by Boavida et al. (2018b), are needed to optimize the implementation of e-flow regimes in river reaches at a regional scale.

Future research on ecohydraulics should embrace not only a multidisciplinary team of biologists, ecologists, fluvial geomorphologists, hydrologists, hydraulicians, environmental and river engineers, natural resource managers, and conservationists, but ecohydraulics should also move forward and engage using interdisciplinary and transdisciplinary (i.e. engagement with end users) approaches.

\section{ACKNOWLEDGEMENTS}

IB was supported by a post-doc grant (SFRH/BPD/90832/2012) from Fundação para a Ciência e a Tecnologia, I.P. (FCT), Portugal. DSH (PD/BD/114440/2016), MM (PD/BD/114336/2016), MDR (SFRH/BD/52513) and MJC (SFRH/BD/ $52517 / 2014$ ) were supported by Ph.D. scholarships funded by FCT, under the Doctoral Programme FLUVIO - River Restoration and 
Management. CEF is a research unit funded by FCT (UID/AGR/00239/2013). Juan F. FuentesPerez contribution is supported by the European Union's H2020 research and innovation program under grant agreement No. 727830, FIThydro and Estonian Research Council grant IUT33-9. Acknowledgments are also due to two anonymous reviewers for their valuable comments and suggestions.

\section{REFERENCES}

ACREMAN, M., A. H. ARTHINGTON, M. J. COLLOFF, C. COUCH, N. D. CROSSMAN, F. DYER, I. OVERTON, C. POLLINO, M. J. STEWARDSON \& W. YOUNG. 2014. Environmental flows for natural, hybrid, and novel riverine ecosystems in a changing world. Frontiers in Ecology and the Environment, 12 (8): 466-473. DOI: 10.1890/130134

ALEXANDRE, C. M., P. R. ALMEIDA, T. NEVES, C. S. MATEUS, J. L. COSTA \& B. R. QUINTELLA. 2016. Effects of flow regulation on the movement patterns and habitat use of a potamodromous cyprinid species. Ecohydrology, 9 (2): 326-340. DOI: 10.1002/eco.1638

ALEXANDRE, C. M., M. T. FERREIRA \& P. R. ALMEIDA. 2015. Life history of a cyprinid species in non-regulated and regulated rivers from permanent and temporary mediterranean basins. Ecohydrology, 8 (6): 1137-1153. DOI: $10.1002 /$ eco. 1572

ARTHINGTON, A. H., A. BHADURI, S. E. BUNN, S. E. JACKSON, R. E. THARME, D. TICKNER, B. YOUNG, M. ACREMAN, N. BAKER, S. CAPON, A. C. HORNE, E. KENDY, M. E. MCCLAIN, N. L. POFF, B. D. RICHTER \& S. WARD. 2018. The Brisbane declaration and global action agenda on environmental flows (2018). Frontiers in Environmental Science, 6: 45. DOI: 10.3389/ fenvs.2018.00045

ARTHINGTON, A. H., S. E. BUNN, N. L. POFF \& R.. J. NAIMAN. 2006. The challenge of providing environmental flow rules to sustain river ecosystems. Ecological Applications: A Publication of the Ecological Society of America, 16 (4): 1311-1318. http://www.ncbi.nlm. nih.gov/pubmed/16937799.
BAIN, M. B., J. T. FINN \& H. E. BOOKE. 1988. Streamflow regulation and fish community structure. Ecology, 69 (2): 382-392. DOI: 10.2307/1940436.

BEJARANO, M. D., R. JANSSON \& C. NILSSON. 2018. The effects of hydropeaking on riverine plants: a review. Biological Reviews, 93 (1): 658-673. DOI: 10.1111/brv.12362.

BELMAR, O., N. VILA-MARTÍNEZ, C. IBÁÑEZ \& N. CAIOLA. 2018. Linking fish-based biological indicators with hydrological dynamics in a Mediterranean river: Relevance for Environmental Flow Regimes. Ecological Indicators, 95 (1): 492-501. DOI: 10.1016/J.ECOLIND.2018.06.073

BELMAR, O., N. VILA, C. IBÁÑEZ, N. CAIOLA, N. VILA-MARTÍNEZ, C. IBÁÑEZ \& N. CAIOLA. 2018. Linking fish-based biological indicators with hydrological dynamics in a Mediterranean river: relevance for environmental flow regimes. In: Book of Abstracts - XIX Conference of the Iberian Association of Limnology. June 24-29, 2018. Coimbra, Portugal.

BENEJAM, L., M. ORDEIX, F. CASALS, N. CAIOLA, A. DE SOSTOA, C. SOLÀ \& A. MUNNÉ. 2015. Fish as ecological indicators in Mediterranean streams: the Catalan experience. In: The Handbook of Environmental Chemistry. 101-123. Springer, Cham. DOI: $10.1007 / 698$ 2015_345

BEVELHIMER, M. S., R.A. MCMANAMAY \& B. O. CONNOR. 2015. Characterizing sub-daily flow regimes: implications of hydrologic resolution on ecohydrology studies. River Research and Applications, 31 (7): 867-879. DOI: 10.1002/rra

BLADÉ, E., L. CEA, G. CORESTEIN, E. ESCOLANO, J. PUERTAS, M.E. VÁZQUEZ-CENDÓN, J. DOLZ \& A. COLL. 2014. Iber: herramienta de simulación numérica del flujo en ríos. Revista Internacional de Métodos Numéricos Para Cálculo y Diseño En Ingeniería, 30: 1-10.

BOAVIDA, I., A. HARBY, K. D. CLARKE \& J. HEGGENES. 2017. Move or stay: habitat use and movements by Atlantic salmon parr (Salmo Salar) during induced rapid flow variations. Hydrobiologia, 785 (1): 261-275. 
DOI: $10.1007 / \mathrm{s} 10750-016-2931-3$

BOAVIDA, I., J. B. JESUS, V. PEREIRA, C. SANTOS, M. LOPES \& R. M. V. CORTES. 2018. Fulfilling spawning flow requirements for potamodromous cyprinids in a restored river segment. Science of the Total Environment, 635: 567-575. DOI: 10.1016/j.scitotenv. 2018.04.167

BOAVIDA, I., R. RIVAES \& J. M. SANTOS. 2018. Transferability of environmental flows: a case-study in a Mediterranean river. In: Book of Abstracts - XIX Conference of the Iberian Association of Limnology. June 24-29, 2018. Coimbra, Portugal.

BOAVIDA, I., J. M. SANTOS, R. CORTES, A. N. PINHEIRO \& M. T. FERREIRA. 2012. Benchmarking river habitat improvement. River Research and Applications, 28 (10): 1768-1779. DOI: 10.1002/rra.1561

BOAVIDA, I., J. M. SANTOS, A. N. PINHEIRO, AND M. T. FERREIRA. 2011. "Fish habitat availability simulations using different morphological variables." Limnetica, 30 (2): 393-404.

BRUNO, M. C., M. J. CASHMAN, B. MAIOLINI, S. BIFFI \& G. ZOLEZZI. 2016. Responses of benthic invertebrates to repeated hydropeaking in semi-natural flume simulations. Ecohydrology, 9: 68-82. DOI: 10.1002/eco.1611

CASAS-MULET, R., E. KING, D. HOOGEVEEN, L. DUONG, G. LAKHANPAL, T. BALDWIN, M. J. STEWARDSON \& J. A. WEBB. 2016. Two decades of ecohydraulics: trends of an emerging interdiscipline. Journal of Ecohydraulics, 1 (1-2): 16-30. DOI: 10.1080/24705357.2016.1251296

CHEN, W. \& J. D. OLDEN. 2018. Evaluating transferability of flow-ecology relationships across space, time and taxonomy. Freshwater Biology, 63 (8): 817-830. DOI: 10.1111/fwb. 13041

CHOW, V. T. 1973. Open channel hydraulics. New York: McGraw-Hill.

CHUN, S. N., S. A. COCHERELL, D. E. COCHERELL, J. B. MIRANDA, G. J. JONES, J. GRAHAM, A. P. KLIMLEY, L. C. THOMPSON \& J. J. CECH. 2010. Displacement, velocity preference, and substrate use of three native
California stream fishes in simulated pulsed flows. Environmental Biology of Fishes, 90 (1): 43-52. DOI: $10.1007 / \mathrm{s} 10641-010-9716-8$

COOMB, S., P. GÖRNER \& H. MUNZ. 2012. Mechanosensory lateral line system. Springer Science \& Business Media.

COOMBS, S., C. B. BRAUN \& B. DONOVAN. 2001. The orienting response of Lake Michigan mottled sculpin is mediated by canal neuromasts. The Journal of Experimental Biology, 204 (Pt 2): 337-348.

COPP, G. H., P. G. BIANCO, N. G. BOGUTSKAYA, T. EROS, I. FALKA, M. T. FERREIRA, M. G. FOX, J. FREYHOF, R. E. GOZLAN, J. GRABOWSKA, V. KOVÁČ, R. MORENO-AMICH, A. M. NASEKA, M. PEŇÁZ, M. POVŽ, M. PRZYBYLSKI, $M$. ROBILLARD, I. C. RUSSELL, S. STAKĖNAS, S. ŠUMER, A. VILA-GISPERT \& C. WIESNER. 2005. To be, or not to be, a non-native freshwater fish? Journal of Applied Ichthyology, 21 (4): 242-262. DOI: 10.1111/j. 1439-0426.2005.00690.x

COSTA, M. J., J. F. FUENTES-PÉREZ, I. BOAVIDA, J. A. TUHTAN \& A. N. PINHEIRO. 2019. Fish under pressure: examining behavioural responses of Iberian barbel under simulated hydropeaking with instream structures. Plos One, 14 (1): e0211115. DOI: 10.1371/journal.pone.0211115

COSTA, M. J., I. BOAVIDA, V. ALMEIDA, S. J. COOKE \& A.N. PINHEIRO. 2018. Do artificial velocity refuges mitigate the physiological and behavioural consequences of hydropeaking on a freshwater Iberian cyprinid? Ecohydrology, e1983. DOI: 10.1002/eco.1983

COSTA, M. J., M. T. FERREIRA, A. N. PINHEIRO \& I. BOAVIDA. 2019. The potential of lateral refuges for Iberian barbel under simulated hydropeaking conditions. Ecological Engineering, 127: 567-578. DOI: 10.1016/J.ECOLENG.2018.07.029

COSTA, M. J., I. BOAVIDA \& A. PINHEIRO. 2018. The consequences of pulsed flows to freshwater fish: challenges and solutions. In: Book of Abstracts - XIX Conference of the Iberian Association of Limnology. June 24-29, 2018. Coimbra, Portugal.

CUSHMAN, R. M. 1985. Review of ecological 
effects of rapidly varying flows downstream from hydroelectric facilities. North American Journal of Fisheries Management, 5: 330-339. DOI: 10.1577/1548-8659(1985) 5<330:ROEEOR $>2.0 . \mathrm{CO} ; 2$

DÍAZ-REDONDO, M., M. MARCHAMALO \& F. MORCILLO. 2018. Biogeomorphic effects of the renaturalization of an urban river: the Manzanares River in the city of Madrid (Spain). In: Book of Abstracts - XIX Conference of the Iberian Association of Limnology. June 24-29, 2018. Coimbra, Portugal.

DOWNS, P. W. \& G. M. KONDOLF. 2002. Post-project appraisals in adaptive management of river channel restoration. Environmental Management, 29 (4): 477-496. DOI: 10.1007/s00267-001-0035-X

EFI+CONSORTIUM. 2009. Manual for the Application of the New European Fish IndexEFI+. A Fish-Based Method to Assess the Ecological Status of European Running Waters in Support of the Water Framework Directive.

EU. 2000. "Water Framework Directive 2000/60/EC." Directive 2000/60/EC of the European Parliament and of the Council of 23 October 2000 establishing a framework for Community action in the field of water policy. FUENTES-PÉREZ, J. F. \& J. A. TUHTAN. 2018. Measuring flow complexity from fish perspective: challenges and opportunities to impact assessment. In: Book of Abstracts XIX Conference of the Iberian Association of Limnology. June 24-29, 2018. Coimbra, Portugal.

FUENTES-PÉREZ, J. F., M. ECKERT, J. A. TUHTAN, M. T. FERREIRA, M. KRUUSMAA \& P. BRANCO. 2018. Spatial preferences of Iberian barbel in a vertical slot fishway under variable hydrodynamic scenarios. Ecological Engineering, 125: 131-142. DOI: 10.1016/J.ECOLENG.2018.10.014

FUENTES-PÉREZ, J. F., J. A. TUHTAN, R. CARBONELL-BAEZA, M. MUSALL, G. TOMING, N. MUHAMMAD \& M. KRUUSMAA. 2015. Current velocity estimation using a lateral line probe. Ecological Engineering, 85: 296-300. DOI: 10.1016/J.ECOLENG. 2015.10.008

GARCIA, A., K. JORDE, E. HABIT, D.
CAAMAÑO \& O. PARRA. 2011. Downstream environmental effects of dam operations: changes in habitat quality for native fish species. River Research and Applications, 27: 312-327. DOI: 10.1002/rra.1358

GASITH, A. \& V. H. RESH. 1999. Streams in Mediterranean climate regions: abiotic influences and biotic responses to predictable seasonal events. Annual Review of Ecology and Systematics, 30 (1): 51-81. DOI: 10.1146/ annurev.ecolsys.30.1.51

GRANT, G. E., J. C. SCHMIDT \& S. L. LEWIS. 2013. A geological framework for interpreting downstream effects of dams on rivers. In: A Peculiar River: Geology, Geomorphology, and Hydrology of the Deschutes River, Oregon, Volume 7. J. E. O'Connor \& G. E. Grant (ed.): 203-219. American Geophysical Union (AGU). DOI: 10.1029/007WS13

GREIMEL, F., J. NEUBARTH, M. FUHRMANN, S. FÜHRER, H. HABERSACK, M. HASLAUER, C. HAUER, P. HOLZAPFEL, S. AUER, M. PFLEGER, S.SCHMUTZ \& B. ZEIRINGER. 2017. "SuREmMa - Sustainable River Management - Energiewirtschaftliche und umweltrelevante bewertung möglicher schwalldämpfender maßnahmen." Wien: IHG-BOKU: https://www.bmnt.gv.at.

GREIMEL, F., B. ZEIRINGER, N. HÖLLER, B. GRÜN, R. GODINA \& S. SCHMUTZ. 2016. A method to detect and characterize sub-daily flow fluctuations. Hydrological Processes, 30 (13): 2063-2078. DOI: 10.1002/hyp.10773

GUMIERO, B., J. MANT, T. HEIN, J. ELSO \& B. BOZ. 2013. Linking the restoration of rivers and riparian zones/wetlands in Europe: sharing knowledge through case studies. Ecological Engineering, 56: 36-50. DOI: 10.1016/j.ecoleng.2012.12.103

HALLERAKER, J. H., S. J. SALTVEIT, A. HARBY, J. V. ARNEKLEIV, H.-P. FJELDSTAD \& B. KOHLER. 2003. Factors influencing stranding of wild juvenile brown trout (Salmo Trutta) during Rapid and Frequent Flow Decreases in an Artificial Stream. River Research and Applications, 19 (5-6): 589-603. DOI: 10.1002/rra.752

HASSAN, EL.-S., H. ABDEL-LATIF \& R. BIEBRICHER. 1992. Studies on the effects of 
$\mathrm{Ca}^{2++}$ and $\mathrm{Co}^{++}$on the swimming behavior of the blind Mexican cave fish. Journal of Comparative Physiology A, 171 (3): 413-419. DOI: $10.1007 / \mathrm{BF} 00223971$

HAUER, C., G. UNFER, P. HOLZAPFEL, M. HAIMANN \& H. HABERSACK. 2014. Impact of channel bar form and grain size variability on estimated stranding risk of juvenile brown trout during hydropeaking. Earth Surface Processes and Landforms, 39 (12): 1622-1641. DOI: 10.1002/ESP.3552

HAVN, T. B., S. A. SÆTHER, E. B. THORSTAD, M. A. K. TEICHERT, L. HEERMANN, O. H. DISERUD, J. BORCHERDING, M. TAMBETS \& F. ØKLAND. 2017. Downstream migration of Atlantic salmon smolts past a low head hydropower station equippped with archimedes screw and francis turbines. Ecological Engineering, 105: 262-275. DOI: 10.1016/J. ECOLENG.2017.04.043

HAYES, D. S., J. M. BRÄNDLE, C. SELIGER, B. ZEIRINGER, T. FERREIRA \& S. SCHMUTZ. 2018. Advancing towards functional environmental flows for temperate floodplain rivers. Science of The Total Environment, 633: 1089-1104. DOI: 10.1016/J. SCITOTENV.2018.03.221

HAYES, D. S., F. GREIMEL, M. HASLAUER, M. FUHRMANN, B. ZEIRINGER, N. HÖLLER, T. FRIEDRICH, C. HAUER, T. FERREIRA \& S. SCHMUTZ. 2018. Response of fish communities to hydropeaking along a morphological gradient. In: Book of Abstracts - XIX Conference of the Iberian Association of Limnology. June 24-29, 2018. Coimbra, Portugal.

JESUS, J., M. C. P. AMORIM, P. J. FONSECA, A. TEIXEIRA, S. NATÁRIO, J. CARROLA, S. VARANDAS, L. T. PEREIRA \& R. M. V. CORTES. 2018. Acoustic barriers as an acoustic deterrent for native potamodromous migratory fish species. Journal of Fish Biology. DOI: $10.1111 / \mathrm{jfb} .13769$

JESUS, J., A. TEIXEIRA, S. NATÁRIO, J. CARROLA, S. VARANDAS, L.T. PEREIRA \& R. M. V. CORTES. 2018. Efeitos de barreira comportamental seletiva com estímulos acústicos, luz e bolhas, no Salmonídeo: $S$. Truta e Ciprinídeos: P. Duriense e L. Bocagei.
In: Book of Abstracts - XIX Conference of the Iberian Association of Limnology. June 24-29, 2018. Coimbra, Portugal.

KARR, J. R. 1981. Assessment of biotic integrity using fish communities. Fisheries, 6 (6): 21-27. DOI: $10.1577 / 1548-8446(1981) 006<$ 0021:AOBIUF $>2.0 . \mathrm{CO} ; 2$

LAMOUROUX, N., S. MÉRIGOUX, H. CAPRA, S. DOLÉDEC, I. G. JOWETT \& B. STATZNER. 2010. The generality of abundance-environment relationships in microhabitats: a comment on Lancaster and Downes (2009). River Research and Applications, 26 (7): 915-920. DOI: 10.1002/rra.1366

LAMOUROUX, N., S. MÉRIGOUX, S. DOLÉDEC \& T. H. SNELDER. 2013. Transferability of hydraulic preference models for aquatic macroinvebrates. River Research and Applications, 29 (7): 933-937. DOI: 10.1002/rra.2578

LANCASTER, J. \& B. J. DOWNES. 2010. Linking the hydraulic world of individual organisms to ecological processes: putting ecology into ecohydraulics. River Research and Applications, 26 (4): 385-403. DOI: 10.1002/rra.1274

LYTLE, D. A. \& N. L. R. POFF. 2004. Adaptation to natural flow regimes. Trends in Ecology and Evolution, 19 (2): 94-100. DOI: 10.1016/j.tree.2003.10.002

MADDOCK, I., A. HARBY, P. KEMP \& P. WOOD. 2013. Ecohydraulics: an integrated approach. Edited by Ian Maddock, Atle Harby, Paul Kemp, and Paul Wood. Hoboken (NJ): Wiley Blackwell.

MAIRE, A., L. BUISSON, J. CANAL, B. RIGAULT, J. BOUCAULT \& P. LAFFAILLE. 2015. Hindcasting modelling for restoration and conservation planning: application to stream fish assemblages. Aquatic Conservation: Marine and Freshwater Ecosystems, 25 (6): 839-854. DOI: 10.1002/aqc. 2566 MONTGOMERY, J. C., C. F. BAKER \& A. G. CARTON. 1997. The lateral line can mediate rheotaxis in fish. Nature, 389 (6654): 960-963. DOI: 10.1038/40135

MOREIRA, M., D. S. HAYES, I. BOAVIDA \& A. P. PINHEIRO. 2018. Hydropeaking thresholds - current status and outlook. In: Book of Abstracts - XIX Conference of the Iberian Association of Limnology. June 24-29, 
2018. Coimbra, Portugal.

MOREIRA, M., D. S. HAYES, I. BOAVIDA, M. SCHLETTERER, S. SCHMUTZ \& A. PINHEIRO. 2019. Ecologically-based criteria for hydropeaking mitigation: a review. Science of The Total Environment, 657: 1508-1522. DOI: 10.1016/J.SCITOTENV.2018.12.107

MOUTON, A. M., M. SCHNEIDER, J. DEPESTELE, P. L. M. GOETHALS \& N. PAUW. 2007. Fish habitat modelling as a tool for river management. Ecological Engineering, 29 (3): 305-315. DOI: 10.1016/j.ecoleng.2006.11.002 MURCHIE, K. J., K. P. E. HAIR, C. E. PULLEN, T. D. REDPATH, H. R. STEPHENS \& S. J. COOKE. 2008. Fish response to modified flow regimes in regulated rivers: research methods, effects and opportunities. River Research and Applications, 24: 197-217. DOI: 10.1002/rra.1058

NESTLER, J. M., C. BAIGUN \& I. MADDOCK. 2016. Achieving the aquatic ecosystem perspective: interdisciplinary integration describes instream hydraulic processes. In: River Science; Research and Management for the 21 st Century, edited by GDJ Greenwood, M Thoms, and P Wood. Hobokes (NJ): Wiley.

NILSSON, C., R. JANSSON, B. MALMQVIST \& R. J. NAIMAN. 2007. Restoring riverine landscapes: the challenge of identifying priorities, reference states, and techniques. Ecology and Society, 12 (1): 1-16.

NOATCH, M. R. \& C. D. SUSKI. 2012. Non-physical barriers to deter fish movements. Environmental Reviews, 20 (1): 71-82. DOI: 10.1139/a2012-001

OLDEN, J. D. \& N. L. POFF. 2003. Redundancy and the choice of hydrologic indices for characterizing streamflow regimes. River Research and Applications, 19 (2): 101-121. DOI: $10.1002 /$ rra.700

OVIDIO, M., H. CAPRA \& J.-C. PHILIPPART. 2008. Regulated discharge produces substantial demographic changes on four typical fish species of a small salmonid stream. Hydrobiologia, 609 (1): 59-70. DOI: 10.1007/s10750008-9399-8

PALAU-NADAL, A., A. PALAU-IBARS \& G. CIUTAT. 2018. Efectos de las hidropuntas de una central hidroeléctrica sobre la organ- ización y estructura de la comunidad de macroinvertebrados bentónicos. In: Book of Abstracts - XIX Conference of the Iberian Association of Limnology. June 24-29, 2018. Coimbra, Portugal.

PALMER, M. A., E. S. BERNHARDT, J. D. ALLAN, P. S. LAKE, G. ALEXANDRE, S. BROOKS, J. CARR., S. CLAYTON, C. N. DAHM, J. FOLLSTAD SHAH, D. L. GALAT, S. G. LOSS, P. GOODWIN, D. D. HART, B. HASSETT, R. JENKINSON, G. M. KONDOLF, R. LAVE, J. L. MEYER, T. K. O'DONNELL, L. PAGANO \& E. SUDDUTH. 2005. Standards for ecologically successful river restoration. Journal of Applied Ecology, 42 (2): 208-217. DOI: 10.1111/j.1365-2664.2005.01004.x.

PETTS, J. 2007. Learning about learning: lessons from public engagement and deliberation on urban river restoration. Geographical Journal, 173: 300-311.

PITCHER, T. J., B. L. PARTRIDGE \& C. S. WARDLE. 1976. A blind fish can school. Science, 194 (4268): 963-965. DOI: 10.1126/SCIENCE.982056

POFF, N. L., J. D. ALLAN, M. B. BAIN, K. L. PRESTEGAARD, B. RITCHER, R. E. SPARKS \& J. C. STROMBERG. 1997. The natural flow regime. Bioscience, 47 (11): 769-784. DOI: 10.2307/1313099

PONT, D., B. HUGUENY, U. BEIER, D. GOFFAUX, A. MELCHER, R. NOBLE, C. ROGERS, N. ROSET \& S. SCHMUTZ. 2006. Assessing river biotic condition at a continental scale: a European approach using functional metrics and fish assemblages. Journal of Applied Ecology, 43 (1): 70-80. DOI: $10.1111 / \mathrm{j} .1365-2664.2005 .01126 . x$

PRETTY, J. L., S. S. C. HARRISON, D. J. SHEPHERD, C. SMITH, A. G. HILDREW \& R. D. HEY. 2003. River rehabilitation and fish populations: assessing the benefit of instream structures. Journal of Applied Ecology, 40 (2): 251-265. DOI: 10.1046/j.1365-2664.2003. 00808.x

RESH, V. H., A. V. BROWN, A. P. COVICH, M. E. GURTZ, H. W. LI, G. W. MINSHALL, S. R. REICE, A. L. SHELDON, J. B. WALLACE \& R. C. WISSMAR. 1988. The role of 
disturbance in stream ecology. Journal of the North American Benthological Society, 7 (4): 433-455. DOI: $10.2307 / 1467300$

RIBI, J.-M., J.-L. BOILLAT, A. PETER \& A. J. SCHLEISS. 2014. Attractiveness of a lateral shelter in a channel as a refuge for juvenile brown trout during hydropeaking. Aquatic Sciences, 76 (4): 527-541. DOI: $10.1007 /$ s00027-014-0351-x

RICE, S. P., S. LITTLE, P. J. WOOD, H. J. MOIR \& D. VERICAT. 2010. The relative contributions of ecology and hydraulics to ecohydraulics. River Research and Applications, 26: 363-366. DOI: 10.1002/rra.1369

RISTOLAINEN, A., K. KALEV, J. A. TUHTAN, A. KUUSIK \& M. KRUUSMAA. 2018. Hydromorphological classification using synchronous pressure and inertial sensing. IEEE Transactions on Geoscience and Remote Sensing, 56 (6): 3222-3232. DOI: 10.1109/TGRS.2018.2795641

RIVAES, R., I. BOAVIDA, J. M. SANTOS, A. N. PINHEIRO \& T. FERREIRA. 2017. Importance of considering riparian vegetation requirements for the long-term efficiency of environmental flows in aquatic microhabitats. Hydrology and Earth System Sciences, 21 (11). DOI: 10.5194/hess-21-5763-2017

ROSENFELD, J. 2003. Assessing the habitat requirements of stream fishes: an overview and evaluation of different approaches. Transactions of the American Fisheries Society, 132 (5): 953-968. DOI: 10.1577/T01-126

SANTOS, J. M., M. T. FERREIRA, A. N. PINHEIRO \& J. BOCHECHAS. 2006. Effects of small hydropower plants on fish assemblages in medium-sized streams in central and northern Portugal. Aquatic Conservation: Marine and Freshwater Ecosystems, 16 (4): 373-388. DOI: 10.1002/aqc.735

SANTOS, J. M., R. RIVAES, I. BOAVIDA \& P. BRANCO. 2018. Structural microhabitat use by endemic cyprinids in a Mediterranean-type river: implications for restoration practices. Aquatic Conservation: Marine and Freshwater Ecosystems, 28 (1): 26-36. DOI: 10.1002/aqc.2839

SAWIN, J. L. \& E. MARTINOT. 2010. Renewables 2010. Global Status Report.
SCHINEGGER, R., M. PUCHER, C. ASCHAUER \& S. SCHMUTZ. 2018. Configuration of multiple human stressors and their impacts on fish assemblages in Alpine river basins of Austria. Science of The Total Environment, 616-617 (March). Elsevier: 17-28. DOI: 10.1016/J.SCITOTENV.2017.10.283

SCHMUTZ, S., T. H. BAKKEN, T. FRIEDRICH, F. GREIMEL, A. HARBY, M. JUNGWIRTH, A. MELCHER, G. UNFER \& B. ZEIRINGER. 2015. Response of fish communities to hydrological and morphological alterations in hydropeaking rivers of Austria. River Research and Applications: 31 (8): 919-930. DOI: 10.1002/rra.2795

SHEN, Y. \& P. DIPLAS. 2010. Modeling unsteady flow characteristics of hydropeaking operations and their implications on fish habitat. Journal of Hydraulic Engineering, 136 (12): 1053-1067. DOI: 10.1061/?ASCE?HY. 1943-7900.0000112

SHUSTER, W. D., Y. ZHANG, A. H. ROY, F. B. DANIEL \& M. TROYER. 2008. Characterizing storm hydrograph rise and fall dynamics with stream stage data. Journal of the American Water Resources Association, 44 (6): 1431-1440. DOI: 10.1111/j.1752-1688.2008. 00249.x

TÁNAGO, M., A. MIRÓ \& D. GARCÍA DE JALÓN. 1999. Evolucion de las poblaciones piscicolas del rio Manzanares aguas abajo del embalse de El Pardo. Limnetica, 17: 13-26.

THARME, R. E. 2003. A global perspective on environmental flow assessment: emerging trends in the development and application of environmental flow methodologies for rivers. River Research and Applications, 19 (5-6): 397-441. DOI: 10.1002/rra.736

TOCKNER, K. \& J. A. STANFORD. 2002. Riverine flood plains: present state and future trends. Environmental Conservation, 29: 308-330. DOI: $10.1017 / \mathrm{S} 037689290200022 \mathrm{X}$

TUHTAN, J. A., J. F. FUENTES-PÉREZ, N. STROKINA, G. TOMING, M. MUSALL, M. NOACK, J. K. KÄMÄRÄINEN \& $M$. KRUUSMAA. 2016. Design and application of a fish-shaped lateral line probe for flow measurement. Review of Scientific Instruments, 87 (4): 045110. DOI: 10.1063/1.4946765 
TUHTAN, JEFFREY A., JUAN FRANCISCO FUENTES-PEREZ， GERT TOMING \& MAARJA KRUUSMAA. 2017. "Flow velocity estimation using a fish-shaped lateral line probe with product-moment correlation features and a neural network." Flow Measurement and Instrumentation, 54 (April). Elsevier: 1-8. DOI: 10.1016/J.FLOWMEASINST. 2016.10.017

TUHTAN, J. A., J. F. FUENTES-PEREZ, G. TOMING, M. SCHNEIDER, R. SCHWARZENBERGER, M. SCHLETTERER \& M. KRUUSMAA. 2018. Man-made flows from a fish's perspective: autonomous classification of turbulent fishway flows with field data collected using an artificial lateral line. Bioinspiration \& Biomimetics, 13 (4): 046006. DOI: 10.1088/1748-3190/aabc79

VEHANEN, T., P. L. BJERKE, J. HEGGENES, A. HUUSKO \& A. MAKI-PETAYS. 2000. Effect of fluctuating flow and temperature on cover type selection and behaviour by juvenile brown trout in artificial flumes. Journal of Fish Biology, 56 (4): 923-937. DOI: 10.1111/j.1095-8649.2000.tb00882.x

WETZEL, R. G. 1981. Limnología. Ediciones Omega.

WHITE, J. C., D. M. HANNAH, A. HOUSE, S. J. V. BEATSON, A. MARTIN \& P. J. WOOD. 2016. Macroinvertebrate responses to flow and stream temperature variability across regulated and non-regulated rivers. Ecohydrology, e1773. DOI: 10.1002/eco.1773

WOOLSEY, S., F. CAPELLI, T. GONSER, E. HOEHN, M. HOSTMANN, B. JUNKER, A. PAETZOLD, C. ROULIER, S. SCHWEIZER, S. D. TIEGS, K. TOCKNER, C. WEBER \& A. PETER. 2007. A strategy to assess river restoration success. Freshwater Biology, 52 (4): 752-769. DOI: 10.1111/j.1365-2427.2007. 01740.x

YOUNG, P. S., J. J. CECH \& L. C. THOMPSON. 2011. Hydropower-related pulsed-flow impacts on stream fishes: a brief review, conceptual model, knowledge gaps, and research needs. Reviews in Fish Biology and Fisheries, 21 (4): 713-731. DOI: 10.1007/ s11160-011-9211-0 